\title{
Iridociliary epithelial cyst
}

\author{
Amar Pujari, Deepa R Swamy
}

Department of Ophthalmology Dr. Rajendra Prasad Centre for Ophthalmic Sciences, AlIMS, New Delhi, India

\section{Correspondence to Dr Amar Pujari, dramarpujari@gmail.com}

Accepted 19 September 2017

\section{DESCRIPTION}

A 26-year-old male patient presented for routine ocular evaluation; visual acuity was 20/20 in each eye with +0.75 dioptre sphere. Bilateral anterior segment examination showed a clear cornea and a normal central anterior chamber depth. In the right eye towards the periphery on temporal aspect, anterior surface of the iris showed irregular anterior elevation (figure 1A, red and yellow arrows) without any loss of its contour or endothelial touch. Lens was crystalline clear, and the pupil was reactive in absence of any posterior synechiae or anterior chamber cells; intraocular pressures were 16 and $14 \mathrm{~mm} \mathrm{Hg}$ in right and left eye, respectively. Left eye anterior segment and retina in both the eyes were essentially within normal limits. Gonioscopy in both the eyes showed open angles without any identifiable

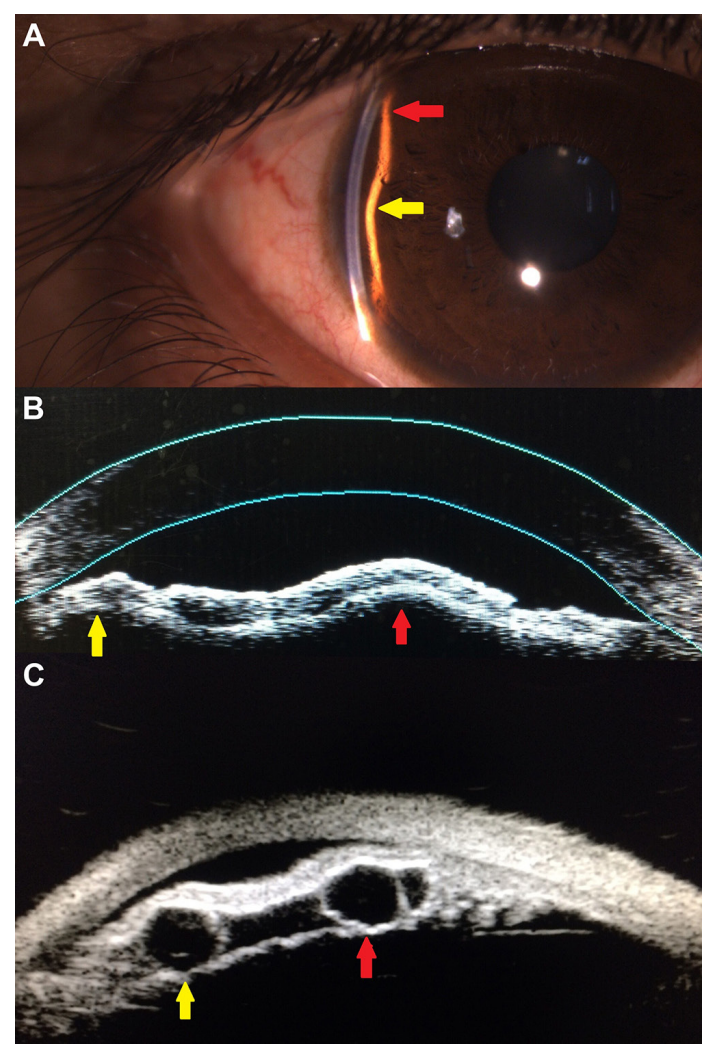

Figure 1 (A) Slit lamp photography showing multiple anterior elevations of the iris (red and yellow arrows). (B) Anterior segment optical coherence tomography revealed anterior elevation of the full-thickness iris at two sites (red and yellow arrows). (C) Ultrasound biomicroscopy showed well-defined two separate cysts (red arrow) underneath the iris resting on the anterior lens capsule (yellow arrow) with internal echoes similar to aqueous humour. pathology. Anterior segment optical coherence tomography (ASOCT) confirmed the anterior elevation of the iris at two sites (figure 1B, red and yellow arrows) which was able to delineate the full thickness of iris until the periphery without much information about the pathology beneath the posterior iris surface. To better understand the pathology behind the iris, ultrasound biomicroscopy (UBM) was performed, which revealed two well-defined cystic cavities (figure 1C, red and yellow arrows) with hyper echoic walls with a hypoechoic centre just beneath the posterior surface of the iris, continuous with the pigmented layer of iris anteriorly and resting on the anterior lens capsule posteriorly (yellow arrow). Based on these findings, a diagnosis of multiple iris cysts was made, and the patient was kept under observation.

Primary iris cysts are usually asymptomatic; there are two types: (1) iris pigment epithelial cyst and (2) iris stromal cysts. ${ }^{1}$ Iris pigment epithelial cysts are usually isolated lesions occurring on the anterior or posterior surface of the iris with stratified squamous pigment epithelial lining. In contrast, the stromal cysts arise from the deeper structures and usually present on the a nterior surface of iris. The iris cysts can be post-traumatic (surgical or non-surgical trauma); these are all benign pathologies that may require intervention when causing significant visual deprivation or amblyopia. The anterior segment tumours such as melanoma, ciliary body medulloepithelioma/melanoma and ocular metastasis from systemic pathologies along the anterior segment structures need a careful evaluation to decide a management plan with optimal visual and systemic outcome. ASOCT basically works using the light rays, which limit the deeper penetration of the mass

Learning points

Patients with anterior chamber irregularities need detailed anterior and posterior segment evaluation with appropriate imaging (ultrasound biomicroscopy is better than anterior segment optical coherence tomography) modalities to delineate the probable in its entirety.

- Iris pigment epithelial cysts are isolated cysts arising from the posterior pigment epithelium; these are benign pathology that usually needs observation and assurance. 
lesion and analysis of the same in its entirety like in this case. In contrast, UBM works by using the ultrasound waves, thus possessing better penetrating abilities. UBM possesses the superiority of delineating the mass lesion in all its borders, anterior and posterior surfaces and changes in the surrounding structures that make it as a preferred modality for the anterior segment tumours. ${ }^{2}$

Contributors Dr Amar and Dr Deepa have evaluated the case clinically in detail and after analysing the educational value Dr Amar and Dr Deepa together wrote the report.

Competing interests None declared.
Patient consent Obtained.

Provenance and peer review Not commissioned; externally peer reviewed.

(C) BMJ Publishing Group Ltd (unless otherwise stated in the text of the article) 2017. All rights reserved. No commercial use is permitted unless otherwise expressly granted.

\section{REFERENCES}

1 Shields JA. Primary cysts of the iris. Trans Am Ophthalmo/ Soc 1981;79:771-809.

2 Bianciotto C, Shields CL, Guzman JM, et al. Assessment of anterior segment tumors with ultrasound biomicroscopy versus anterior segment optical coherence tomography in 200 cases. Ophthalmology 2011;118:1297-302.

Copyright 2017 BMJ Publishing Group. All rights reserved. For permission to reuse any of this content visit http://group.bmj.com/group/rights-licensing/permissions.

BMJ Case Report Fellows may re-use this article for personal use and teaching without any further permission.

Become a Fellow of BMJ Case Reports today and you can:

- Submit as many cases as you like

- Enjoy fast sympathetic peer review and rapid publication of accepted articles

- Access all the published articles

- Re-use any of the published material for personal use and teaching without further permission

For information on Institutional Fellowships contact consortiasales@bmjgroup.com

Visit casereports.bmj.com for more articles like this and to become a Fellow 